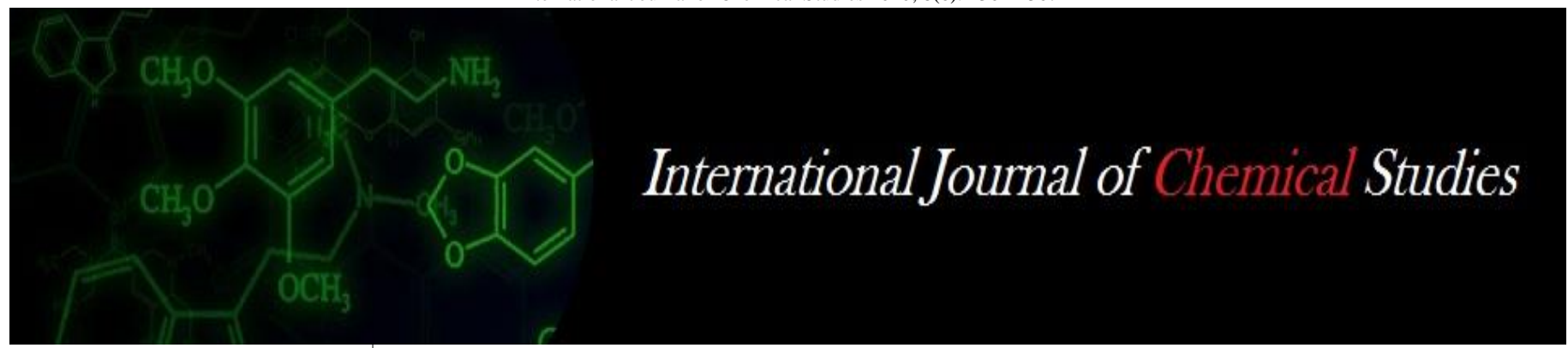

P-ISSN: 2349-8528

E-ISSN: 2321-4902

www.chemijournal.com

IJCS 2020; 8(6): 2362-2367

(C) 2020 IJCS

Received: 16-09-2020

Accepted: 14-11-2020

Bhagyalaxmi Pahi

School of Agriculture,

Lovely Professional University,

Phagwara, Punjab, India

Chandan Kumar Rout

School of Agriculture,

Lovely Professional University,

Phagwara, Punjab, India

Deepika Saxena

School of Agriculture,

Lovely Professional University,

Phagwara, Punjab, India
Corresponding Author:

Deepika Saxena

School of Agriculture,

Lovely Professional University,

Phagwara, Punjab, India

\section{Effects of gibberellic acid (GA3) on quality and yield in grapes}

\section{Bhagyalaxmi Pahi, Chandan Kumar Rout and Deepika Saxena}

DOI: https://doi.org/10.22271/chemi.2020.v8.i6ah.11126

\begin{abstract}
Grape (Vitis vinifera L.) is one in every of the most precious fruit plants of temperate regions, but it is successfully grown in tropical and sub-tropical agro-climatic situations. This review is undertaken to evaluate the effects of gibberellic acid on the Quality and yield of grapes. The plant hormones are extraordinarily essential agents inside the integration of developmental activities. $\mathrm{GA}_{3}$ is also called gibberellic acid, but the term gibberellic is often used in describing all gibberellins. Active gibberellins show many physiological effects, each depending on the type of gibberellin present in the grape plant. This review Results suggest foliar sprays of only gibberellic acid (combine with different chemicals) with various concentrations at the different developmental stages, increases both quality and yield in grapes.
\end{abstract}

Keywords: Gibberellic acid ( $\left.\mathrm{GA}_{3}\right)$, quality, yield, grapes

\section{Introduction}

Grape (Vitis vinifera L.) is the most precious fruit plants of the temperate region which has acclimatized to tropical and sub-tropical agro-climatic situations. It belongs to the Vitaceae family, originated in Western Asia and Europe. It was introduced to India in $1300 \mathrm{~A}$. D by the Persian invaders. Grape is a famous and economically valuable fruit [Ruel JJ \& Walker MA (2006)] ${ }^{[34]}$ around the globe Grapes production became calculated about 74.5 million tons from the growing area of 7.12 million hectares [FAO (2014)] ${ }^{[16]}$. China, Italy, USA, Spain, France, Turkey, Argentina, India, and Iran [FAO (2017)] ${ }^{[17]}$ is the leading producer of the grapes in India grape is cultivated in an area of 45,200 ha with an annual production of 10.57 lakh tones (Mani, 2014) ${ }^{[33]}$.

Grapes is a non-climacteric fruit that grows at deciduous woody and the perennial climbing vine. Grapes is a cross-pollinated vine with easy, lobed, cut, or toothed leaves (seldom compound) with racemes of greenish plants, the fruit along with the watery or fleshy pulp, stones, and skin, four-seeded. Grape is a fairly appropriate supply of minerals like calcium, phosphorous, iron, and nutrients like B1 and B2. Fresh and dried culmination has numerous uses in Ayurvedic and Unani medicinal drugs.

PGR is usually applied in order to improve the berry size and quality of grapevine (Rusjan, 2010) ${ }^{[44]}$. Gibberellic acid (GA3) is used widely for improving yield and fruit quality. GA3 is applied to grape cultivars during the fruit set to increase berry size (Peacock and Beede, 2004) studies have established that bioactive GAs are involved in key aspects of plant development, like seed germination, flower induction, fruit and seed development [Hedden P \& Kamiya Y (1997)] ${ }^{[24]}$. Berry quality is influenced by both exogenous (e.g., temperature, light, and water availability) and endogenous factors (e.g., nutritional and hormonal factors) [Ollat et al. (2002)] ${ }^{[41]}$. Seediness is controlled by endogenous growth promoters [May P (2000)] ${ }^{[36]}$. The presence of berry is significantly correlated with endogenous gibberellins [Gokturk N \& Harmankaya N (2005)] [21] and growth retardants. Substances such as 2-chloroethyl trimethylammonium chloride (CCC) increase fruit set but reduce berry size and sugar accumulation by inhibiting gibberellin synthesis [Looney NE (1981)] ${ }^{[31]}$. These substances did not harm the plant and environment. The influence of Gibberellins $\left(\mathrm{GA}_{3}\right)$ is observed in tomato and other vegetables for parthenocarpic fruit induction through the exogenous application. $\mathrm{GA}_{3}$ induce fruit development in unfertilized ovaries. $\mathrm{GA}_{3}$ also overcome the suspended growth of dormant pollinated ovaries [Magdalena et al. (2017)] ${ }^{[32]}$ 


\section{Structure of Gibberellic acid (GA3)}

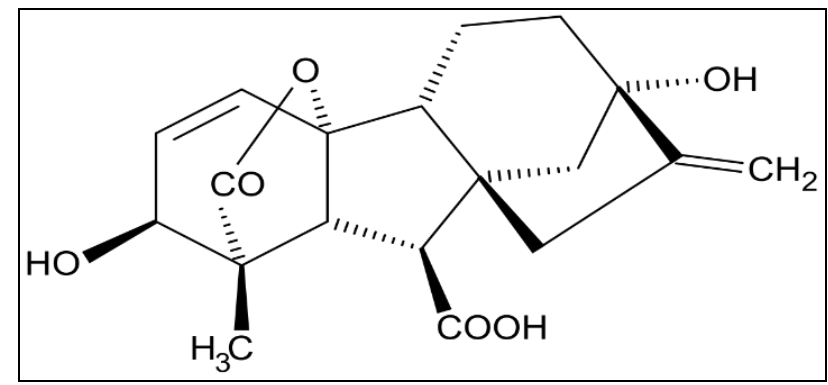

Fig 1: Effects of Gibberellic acid $\left(\mathrm{GA}_{3}\right)$ on quality and yield in grapes

Anjum et al. (2020) ${ }^{[5]}$ observed that foliar applications were applied to get to and normalize the ideal portion of $\mathrm{GA}_{3} 100$ $\mathrm{mg} / \mathrm{L}, 200 \mathrm{mg} / \mathrm{L}$, and $300 \mathrm{mg} / \mathrm{L}$ dosages alongside control. It was seen that the use of $\mathrm{GA}_{3} @ 300 \mathrm{mg} / \mathrm{L}$ essentially improved berry weight, berry size, and cluster weight but quantities of berries per bunch were decreased. While total soluble solids (TSS) were essentially increased with application $200 \mathrm{mg} / \mathrm{L}$ of $\mathrm{GA}_{3}$ while titratable causticity (TA) was diminished in gibberellin treatment when contrasted with control. Gadissa et al. (2020) ${ }^{[19]}$ evaluated that the experiment included ten treatments developed via a factorial combination of five levels of $\mathrm{GA}_{3}$ and two levels of the canopy. These treatments were complete based on a randomized block design with three replications. $\mathrm{GA}_{3}$ was sprayed when the cluster length 8-10 $\mathrm{cm}$ before flowering and after fruit set plus canopy management (first- hedging and leaf base thinning was done at the height of $45 \%$ length of shoots from the arm after flowering and the second was done by removing lateral growth one month after the first Hedging. The results revealed that significantly gibberellic acid increased berry length, berry size, berry weight and Hedging, and leaf base thinning affect the total number of berry per cluster. But exogenous application $90 \mathrm{mg} \mathrm{GA}_{3}$ /cluster showed better economic return without canopy management.

Gao et al. (2020) ${ }^{[20]}$ found that the application of $50-100 \mathrm{mg} / \mathrm{L}$ $\mathrm{GA}_{3}$ prior to grape vine, showed elongation of inflorescences and bunches and eased cluster compactness in Cabernet Franc (CF) and Cabernet Sauvignon(CS), while no negative effects were observed on the yield and seed number. Ali et al. (2019) observed that among all treatments (control, 1ppm $\mathrm{GA}_{3}, 1 \mathrm{ppm}$ $\mathrm{GA}_{3}+5000 \mathrm{ppm}$ Low-biuret Urea, 2ppm GA 3 , and 5000ppm Low-biuret Urea), the results showed that $1 \mathrm{ppm}$ GA3+5000ppm Low-biuret Urea treatment improved growth and high-quality clusters of Red globe table grape. Mohamed et al. (2019) [38] evaluated that exogenous application of Abscisic Acid (ABA), Gibberellic Acid $\left(\mathrm{GA}_{3}\right)$ on three important grape cultivars (Flame Seedless, Ruby Seedless, and Thompson Seedless), the result revealed that all individual abscisic acid treatements at two hundred, four hundred and six hundred ppm and ABA at 400 ppm mixed with $\mathrm{GA}_{3}$ at $10 \mathrm{ppm}$ remarkable increased in yield weight $(\mathrm{kg} / \mathrm{vine})$ comparing with the control treatment.

Eleonora et al. (2018) ${ }^{[15]}$ determined that gibberellic acid treatments and girdling influenced by the climate in the growing season and ripening stage increased the average cluster weight and berry dimensions and Quality of Vitis vinifera L. cv. Victoria and Italia table. Da Silva et al. (2018) ${ }^{[13]}$ evaluated the impact of various doses of gibberellic acid $\left(\mathrm{GA}_{3}\right)$ on rot incidence of 'Pinor Noir' grapevine. The treatments of $\mathrm{GA}_{3}$ doses i.e., $0,2,4,6$ and $8 \mathrm{mg} \mathrm{L}^{-1}$ applied at the developed inflorescence on 14-year-old plants, the results showed the utility of $\mathrm{GA}_{3}$ doses of 4,6 and $8 \mathrm{mg} \mathrm{L}^{-1}$, confirmed higher cluster length, rachis length and also decreased clusters rotting compared to the control. Athani et al. (2018) ${ }^{[6]}$ determined that the test changed into carried out to look at the impact of gibberellic acid on different grape varieties. Two exclusive schedules of gibberellic acid treatment viz.,schedule-1 [10 ppm $\mathrm{GA}_{3}$ at parrot green stage as spray+ 20 ppm $\mathrm{GA}_{3}$ during 1 week of 1 st spray as spray + 30 ppm $\mathrm{GA}_{3}$ at 3-4 mm berry size stage as bunch dipping + 40 ppm $\mathrm{GA}_{3}$ at $8-10 \mathrm{~mm}$ berry size stage as bunch dipping + $50 \mathrm{ppm} \mathrm{GA}_{3}$ as bunch dipping during 1 week after 4th treatment] and schedule-2 [20 ppm $\mathrm{GA}_{3}$ at anthesis stage as dipping +50 ppm $\mathrm{GA}_{3}$ at berry set stage as dipping] were applied to four exclusive styles of grape viz., Thompson seedless, Manik Chaman, KR White, and 2-A Clone, The effects revealed that most berry duration, berry diameter, berry weight, pulp weight, peel weight and pulp: peel ratio, berry firmness and minimal weight reduction for 12 days, the minimal range of rotten berries had been recorded within the grapes treated with a schedule-1 set of gibberellic acid as compared to that of the schedule- 2 set of gibberellic acid treatment.

Noori et al. (2018) ${ }^{[41]}$ evaluated the effect of phosphorus and gibberellic acid on the boom and yield of grape (Vitis vinifera L.). The first thing on this experiment changed into $\mathrm{P} 2 \mathrm{O} 5$ with three levels $(0,5$, and $10 \mathrm{~g} / \mathrm{l})$ supplied through phosphatic fertilizer containing $46 \%$ phosphorus, and the second one factor becomes gibberellic acid with three concentrations $(0,100$ and $200 \mathrm{ml} / \mathrm{l})$. The outcomes of this observe confirmed good-sized consequences of phosphorus and gibberellic acid on leaf vicinity, chlorophyll content material, carbohydrates, cluster-wide variety, cluster weight, wide fruit variety, juice intensity, total soluble solids, and overall acidity of the grape. Magdalena et al. (2017) [32] evaluated yield and Quality after one, two, or three spray applications of $\mathrm{GA}_{3}$ (7, 14 and 21 days after full bloom) at 100,200 and $300 \mathrm{mg} / \mathrm{l}$, three times spray showed higher yields, cluster weight and berry weight than treatments performed once or twice. Alrashdi et al. (2017) determined that pre-harvest application of gibberellin and salicylic acid on 'El-Bayadi' table grapes, showed $\mathrm{GA}_{3}$ spray increased berry size (weight, length, and width), Vitamin $\mathrm{C}$, Peroxidase (POD) polyphenol oxidase (PPO), polygalacturonase (PG) and xylanase activities as compared to salicylic acid. This results revealed $\mathrm{GA}_{3}$ increased overall Quality of 'El-Bayadi' table grapes.

Kumar et al. (2017) ${ }^{[19]}$ evaluated the effect of $\mathrm{GA}_{3}$ in mixture with Urea Phosphate and BA on yield and exceptional parameters of grape cv. Thompson Seedless. Ten concentration of $\mathrm{GA}_{3}$ in aggregate with Urea Phosphate and BA and control (water spray) had been implemented at ranges that have been pre-bloom and berry set. Among all of the combined applications, both $\mathrm{GA}_{3}$ and $\mathrm{BA}$ at distinctive

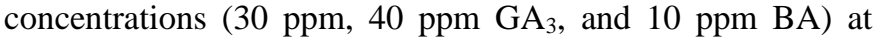
stages (pre-bloom and berry set) improved fruit parameters like berry size, width, weight, and the number of grapes per bunches. Nanjappanavar et al. (2017) ${ }^{[40]}$ evaluated Quality and yield of grapes cv. Manik Chaman by application of five treatments of gibberellic acid i.e., T1-Gibberellic acid $0.001 \%$ L $120 \mathrm{ml} / \mathrm{ac}$, T2-Gibberellic acid $0.001 \%$ L $180 \mathrm{ml} / \mathrm{ac}, \mathrm{T} 3-$ Gibberellic acid $0.001 \%$ L $240 \mathrm{ml} / \mathrm{ac}$, T4-Gibberellic acid $0.001 \%$ L $180 \mathrm{ml} / \mathrm{ac}$ (Standard check) T5-Control. Among the treatments, T2-Gibberellic acid 0.001\% L @ $180 \mathrm{ml} / \mathrm{ac}$ bunch dipping at 30 days after forwarding pruning and at match head 
stage, out of all treatments T2-Gibberellic acid 0.001\% L @ $180 \mathrm{ml} / \mathrm{ac}$ revealed higher bunch weight, yield per vine and yield per ha and Also found superior quality parameters. Filimon et al. (2016) evaluated that test becomes performed by using spraying the inflorescences with $25 \mathrm{ppm}, 50 \mathrm{ppm}$, and 100 ppm $\mathrm{GA}_{3}$. The end result found out that $\mathrm{GA}_{3} @ 25$ ppm confirmed better yield, and high-quality with equilibrated sugar/acid ratio, a higher accumulation of anthocyanins and phenolic compounds in berries, improving the economic factor of grapes by way of increasing coloration intensity and uniformity.

Camc1 (2016) ${ }^{[8]}$ Evaluated that the test was based on results of applications on grape yield and quality characteristics of Cluster via Tipping (CT), Girdling (G), CT+G, $\mathrm{GA}_{3}+\mathrm{CT}$, $\mathrm{GA}_{3}+\mathrm{G}, \mathrm{GA}_{3}+\mathrm{G}+\mathrm{CT}$, the consequences confirmed all packages had widespread outcomes on grape yield, cluster weight, cluster width, berry period, berry width, berry duration/berry width, soluble solids and titratable acidity in Superior Seedless but this study, recommended $\mathrm{GA}_{3}+\mathrm{G}$ the most suitable application for growing Superior Seedless table grape variety. Sangeetha et al. (2015) ${ }^{[47]}$ Saw that the use of $\mathrm{GA}_{3}$ by showering with plunging strategy recorded the most noteworthy berry weight, berry width, heaviest packs, and best return per vine and further more recorded high absolute solvent solids, $\mathrm{pH}$ and lower titrable acid compare to control. Shamim-ul-Subtain Shah et al. (2015) ${ }^{[49]}$ discovered that Different concentrations of $\mathrm{GA}_{3}$ (15ppm, 20ppm, and 25ppm) had been carried out to grape CV. Perlet as Bloom treatment in two splits doses. The first spray became applied at $70-80 \%$ bloom and accompanied with the aid of the second spray as the post-bloom treatment, just after fruit set, they noticed Maximum berry weight, length berry width, and TSS had been recorded at 25ppm. Mohsen et al. (2015) ${ }^{[39]}$ evaluated result of this study revealed that spraying $\mathrm{GA}_{3}$ at $0.5 \mathrm{mg} / \mathrm{l}$ at full bloom was the optimum treatment for Crimson Seedless berry thinning, this treatment showed improved bunch and berry physical and chemical characteristics, in addition to the packable yield of tested table grape cv. Without a better reduction in a number of berries/ bunch, as well as yield and bunch weights as compared with the alternative tested $\mathrm{GA}_{3}$ concentrations and control.

Samra et al. (2015) ${ }^{[46]}$ evaluated that impact of spraying "Flame Seedless" grapes with gibberellic acid $\left(\mathrm{GA}_{3}\right)$ and ethephon at $250 \mathrm{ppm}$ while berry length was about 10, 12 and $14 \mathrm{~mm}$ on berry color and Quality, consequences found out that combined spray of ethephon at $250 \mathrm{ppm}$ with $\mathrm{GA}_{3}$ when berry length was approximately $14 \mathrm{~mm}$ considerably expanded cluster weight, berry weight, and yield/ vine than the single treatment of ethephon and $\mathrm{GA}_{3}$. Abu-Zinada (2015) found that test based on sprayed with $\mathrm{GA}_{3}$ at $10(\mathrm{G} 1), 15$ (G2), 20 (G3), 30 (G4) or 40ppm (G5) on 'Parletta' cultivar of grape whilst the cluster changed into the $7-12 \mathrm{~cm}$ length (S1), at full bloom (S2) or while berry became $2-4 \mathrm{~mm}$ (S3). He concluded that Spraying with $\mathrm{GA}_{3}$ at 15 ppm when cluster 7$12 \mathrm{~mm}$ increased berry size and quality. Tian (2014) [51] observed that the experiment based on the effect of $\mathrm{GA}_{3}$ application on content and antioxidant activity of phenolic compounds in different tissues of Muscat grapevine (Vitis vinifera L. 'Muscat'), the study showed application $\mathrm{GA}_{3} 100$ $\mathrm{mg} \mathrm{L}^{-1}$ induced seedless grape berries, enhanced berry size and accelerated the development of berries, resulting in earlier ripening of seedless berries and also increased total phenolics and flavonoids, and antioxidant activity of leaves, stem, and tendrils.
Kukali et al. (2014) ${ }^{[28]}$ studied the effect of $\mathrm{GA}_{3}$ at various concentration (75-100-125 $\mathrm{mg} / \mathrm{L}$ ) on grapes to evaluate the Production and Quality Improvements, Results confirmed that all treatments showed an acceleration of the flowering, maturation and also increased berry size, weight and sugar content in fruit. Cotovanu-Filimon et al. (2013) ${ }^{[12]}$ evaluated that the anthocyanin content variant underneath the has an effect on of treatments with gibberellic acid $\left(\mathrm{GA}_{3}\right)$ at a few table grape varieties (Vitis vinifera L.), the results discovered the application of gibberellic acid extended productivity \& quality, and also accelerated anthocyanin in some varieties i.e., Coarna Neagra. He et al. (2013) ${ }^{[23]}$ studied on effects of different concentrations of gibberellic acid treatment on berry quality and sugar metabolism during the grape berries development, and the study showed that application $\mathrm{GA}_{3}$ increased average fruit weight, total soluble content and also increased in Ca2+-ATPase activity. Ozer et al. (2012) evaluated that effects of gibberellin $\left(\mathrm{GA}_{3}\right)$ on yield and fruit quality of Reçel Uzumu table grapes, by treatment of $\mathrm{GA}_{3}$ ( $40 \mathrm{ppm}$ ) was applied at the $3-5 \mathrm{~mm}$ berry size stage. The study showed $\mathrm{GA}_{3}$ was the main factor for the increase in berry size, berry and cluster weight, and yield and also delayed fruit maturity. Juan et al. (2012) ${ }^{[25]}$ observed that treatments with $\mathrm{GA}_{3}$ and 6-BA on of 5-years-old Red Globe, the results showed treatment with $50 \mathrm{mg} / \mathrm{kg} \mathrm{GA}_{3}+20 \mathrm{mg} / \mathrm{kg}$ 6-BA promoted more growth and development of grape berry, and increase the yield than the individual treatment with 50 $\mathrm{mg} / \mathrm{kg} \mathrm{GA}$. Meena et al. (2012) ${ }^{[37]}$ observed that application of Gibberellic acid $\left(\mathrm{GA}_{3}\right)$ with different concentration @ 20, 25 , and $50 \mathrm{ppm}$ on fruit developmental stage, concentration 25 ppm spray showed maximum yield and reduced decay percentage $(0.16 \%)$ up to the third week of storage of grape. Dimovska et al. (2011) ${ }^{[14]}$ studied that the application of three concentration levels of gibberellic acid @ 5,10 and $20 \mathrm{mg} / \mathrm{L}$ on three different periods of the vine growing: before blooming, after blooming and before veraison, this test showed that the concentration of $\mathrm{GA}_{3}$ had an effect on the physiological characteristics of the berries in all grapegrowing periods and gibberellic acid at a dose of twenty $\mathrm{mg} / \mathrm{L}$ increased the cluster and berry weight of two seedless varieties i.e., Thompson and Belgrade. Kaplan (2011) [26] studied on yield quality of 'Einset Seedless' grape after the application of gibberellic acid $\left(\mathrm{GA}_{3}\right)$ with concentration 100 $\mathrm{mg} \times \mathrm{L}^{-1}$ at full flowering (70-80\% of open flowers) and 50 $\mathrm{mg} \times \mathrm{L}^{-1}$ applied twice: at the beginning of flowering (20\% of open flowers), and the second time at the end of flowering (80\% of faded flowers) and combined application of 50 $\mathrm{mg} \times \mathrm{L}^{-1} \mathrm{GA}_{3}+0.2 \% \mathrm{NOA}$ at full flowering; and single treatment of NOA @ $0.2 \%$ at full flowering stage. The results showed that treatments had a favourable effect on berry weight as well as on the number of berries per cluster. Chaitakhob et al. (2011) ${ }^{[10]}$ evaluated that the experiment was conducted on 7-year-old 'Perlette' grape trained on T-trellis system, to investigate the effect of bunch dipping with $\mathrm{GA}_{3}$ and N6-benzyl adenine (BA), the results revealed that bunch dipping with $30 \mu \mathrm{L} \mathrm{L}^{-1} \mathrm{GA}_{3}$ (at $50 \%$ of full bloom) and $10 \mu \mathrm{l}$ $\mathrm{L}^{-1} \mathrm{BA}$ (at pea size) significantly reduced the seed formation and improved the yield and quality in 'Perlette' grape.

Rusjan (2010) ${ }^{[44]}$ studied on impacts of the gibberellin $\left(\mathrm{GA}_{3}\right)$ application on grapevine (Vitis vinifera L.) varieties 'Cardinal' and 'Michele Palieri,' on grape quality and their storage potential, the treatment with $\mathrm{GA}_{3} @ 50 \mathrm{ppm}$ showed highest total sugar concentration \& CIRG indices and the quality of table grape responded differently to $\mathrm{GA}_{3}$ applications, especially the different impacts were observed 
according to varieties. Satidtawat (2009) ${ }^{[48]}$ evaluated that effects of berry thinning period and $\mathrm{GA}_{3}$ software to berry size and best of Beauty Seedless grapes, The result revealed that $\mathrm{GA}_{3}$ application @ 25 and 50 ppm to 14 and 21 days after full-bloom collectively with berry thinning earlier than or after $\mathrm{GA}_{3}$ utility was considerably increasing the berries length and tended to increase boom cluster size \& weight. Lamjaroenphong (2009) ${ }^{[30]}$ Studied on the effect of berry thinning period and gibberellic acid $\left(\mathrm{GA}_{3}\right)$ application at 14 days and 21 days after full bloom to determined berry size and quality of 'Perlette, the study showed that $\mathrm{GA}_{3}$ at a concentration of $25 \mathrm{ppm}$ at 14 days after full-bloom with berry thinning before or after $\mathrm{GA}_{3}$ application gave berry size more than $\mathrm{GA}_{3}$ at a concentration of $50 \mathrm{ppm}$ and also know $\mathrm{GA}_{3}$ at concentrations of 25 and $50 \mathrm{ppm}$ at 14 and 21 days after full-bloom tended to increase total soluble solids than the untreated. Khan et al. (2009) ${ }^{\text {[27] }}$ observed that sprayed with GA3 at the concentrations of $15 \mathrm{ppm}, 20 \mathrm{pp}$, and $25 \mathrm{ppm}$ at $80 \%$ blooming, and a week later fruit set on the flame seedless grape cultivar, It was seen that the use of GA3@25 ppm showed Maximum berry weight, width, length, TSS and cluster weight.

Warusavitharana et al. (2008) ${ }^{\text {[53] }}$ evaluated that effect of Cytokinins and Brassinosteroid with Gibberellic acid on Yield and Quality of Thompson Seedless Grapes, and the results showed application of $\mathrm{GA}_{3}$ at $10 \mathrm{ppm}$ at before blooming stage, $15 \mathrm{ppm}$ at after flowering initiation, $25 \mathrm{ppm}$ mixed with brassinosteroid@1 ppm, and benzyl adenine @10 ppm at 3 to $4 \mathrm{~mm}$ berry diameter stage in twice at 4 leaves and berry setting stage and found maximum berry diameter, berry length, berry weight, number of berries per bunch, number of bunches per vine, bunch weight and yield with the attractive grayish-yellow color of berries. Casanova et al. (2007) Located that application of Gibberellic acid @80 mg /L at fruit set to 21 days afterward on 'Emperatriz' seedless grape, showed berry weight accelerated by $50 \%-90 \%$ and the impact befell via larger berry growth rate, early glucose, fructose, and sucrose uptake, growth of absolute glucose $\&$ fructose content (mg berry-1) of seedless berries and growth of absolute berry water content material. Wassel et al. (2007) ${ }^{[54]}$ found that combined application of micronutrients( $\mathrm{Zn}, \mathrm{Fe}$, and $\mathrm{Mn})$ at $0.2 \%$, gibberellic acid at $25 \mathrm{ppm}$, and ascorbic acid at 500 ppm on white Banaty seedless grapevines, the results showed the maximum weight of clusters and number of clusters per vine that indicated remarkable promotion on yield.

Tecchio et al. (2006) ${ }^{[50]}$ observed that dipping clusters into aqueous solutions of CPPU @ 0, 15, 30, 45, 60, 75 and 90 mg/litre and $\mathrm{GA}_{3} @ 0,30,60,90,120,150$ and 180 mg/litre , showed both growth regulators treatments increased weight, length and width of fruits. Chen et al. (2005) ${ }^{[11]}$ observed that experiments had been conducted on Red Globe grape cultivar for analyzing the influence of girdling and gibberellic acid utility at the berry weight, cluster weight, seed variety consistent with berry, the consequences showed that trunk girdling conducted while the berry diameter grew up to fifteen-sixteen $\mathrm{mm}$ extended the berry weight with the aid of $10 \%$, and that dipping cluster with $\mathrm{GA}_{3} 40-60 \mathrm{mg} / \mathrm{L}$ expanded the berry weight and cluster weight substantially. Usha et al. (2005) ${ }^{[52]}$ Studied on the experiment was conducted on a 3year-antique grape CV. Perlette educated on pergolas, to research the impact of bunching dipping with $\mathrm{GA}_{3}$ and N6benzyl adenine (BA) on lowering the problem of shot berries and enhancing the productiveness of grapevines, the take a look at discovered that bunch dipping with $30 \mu \mathrm{L} / \mathrm{L} \mathrm{GA}_{3}$ (at $50 \%$ of complete bloom) and $10 \mu \mathrm{L} / \mathrm{L}$ BA (at pea size) considerably decreased the trouble of shot berries, and improved the yield and first-rate in grape cv. Palette.

Avenant \& Avenant (2005) ${ }^{[7]}$ Effect of gibberellic acid and CPPU on colour and berry size of 'redglobe' grapes. The combined applications of $20 \mathrm{mg} \mathrm{L}^{-1} \mathrm{GA} 3$ plus $5 \mathrm{mg} \mathrm{L}^{-1} \mathrm{CPPU}$ plus $1.5 \%$ seaweed at $12 \mathrm{~mm}$ berry size, $16 \mathrm{~mm}$ berry size and véraison stage, results showed highest yield with a desirable colour. Gowda et al. (2005) ${ }^{[22]}$ Studied at the influence of the utility of $\mathrm{GA}_{3}$ on the increase and development of bunches and berries of 'Thompson Seedless grapes (Vitis vinifera L.), the results discovered that utility of $\mathrm{GA}_{3}$ at 20, 25, 30 and 40 $\mathrm{mg} \mathrm{L}^{-1}$ at $45,50,55$ and 65 days after October pruning was observed to be higher yield and good quality of 'Thompson Seedless grapes below Bangalore situations.

\section{Conclusion}

This review is undertaken to evaluate the effects of gibberellic acid on the quality and yield of grapes. Significance application of $\mathrm{GA}_{3}$ at different developmental stage (flowers and fruits) was increase yield and maintained the quality of grapes as compare to control. This review shows exogenous application of different concentrations of $\mathrm{GA}_{3}$ is beneficial for quality and yield of various cultivars of grapes.

\section{References}

1. Abu-Zinada IA. Effect of GA3, Girdling or Pruning on Yield and Quality of' Parletta' Seedless Grape. American Journal of Agriculture and Forestry 2015;3(5):230-233.

2. Al-Atrushy SMM. Effect of GA3 Concentration and Frequency on Yield and Quality of' Zark' Grape. Jordan Journal of Agricultural Sciences 2016;12(4):1183-1191.

3. Ali FSMAA. Foliar spray of Gibberellin (GA3) and Urea to improve growth, yield, bunch and berry quality of Red globe grapevine.

4. Alrashdi AM, Al-Qurashi AD, Awad MA, Mohamed SA, Al-rashdi AA. Quality, antioxidant compounds, antioxidant capacity and enzymes activity of 'ElBayadi'table grapes at harvest as affected by preharvest salicylic acid and gibberellic acid spray. Scientia Horticulturae 2017;220:243-249.

5. Anjum N, Feroze MA, Rafique R, Shah MH. 7. Effect of gibberellic acid on berry yield and quality attributes of grapes cv. sultanina. Pure and Applied Biology (PAB) 2020;9(2):1319-1324.

6. Athani SI, Sagar DC, Patil DR, Gopali JB, Basavraj N, Manukumar HR et al. Effect of gibberellic acid on quality of different grape varieties under northern dry zone of Karnataka. Annals of Horticulture 2018;11(2):169-174.

7. Avenant JH, Avenant E. Effect of gibberellic acid and cppu on colour and berry size of' redglobe' grapes in two soil types. In $\mathrm{X}$ International Symposium on Plant Bioregulators in Fruit Production 2005;727:371-380.

8. Camc1 H. The effects of applications GA3, cluster tipping and girdling on yield and quality in superior seedless (Vitis vinifera L.) grape variety. Ege Üniversitesi Ziraat Fakültesi Dergisi 2016;53(3):351-358.

9. Casanova Lerma L, Casanova R, Moret A, Agustí M. The application of gibberellic acid increases berry size of 'Emperatriz'seedless grape. Spanish Journal of Agricultural Research 2009;7(4):919-927.

10. Chaitakhob N, Janchean B, Pilap N, Methaneekornchai S. Influence of gibberellic acid and n6-benzyladenine on the development of seed and berry quality in'Perlette'seedless 
grape. In International Symposium on Tropical and Subtropical Fruits 2011;1024:197-203.

11. CHEN JY, FANG JB, GU H, Zhang WY, WEI SZ. Influence of girdling and gibberellic acid application on the fruit characteristics of Red Globe grape cultivar [J]. Journal of Fruit Science, 2005, 6.

12. Coțovanu-Filimon R, Rotaru L, Filimon R. Anthocyanin content variation under the influence of treatments with gibberellic acid (GA3) at some table grape varieties (Vitis vinifera L.) grown in iasi vineyard area. Lucrări Ştiințifice, Universitatea de Științe Agricole Și Medicină Veterinară" Ion Ionescu de la Brad" Iași, Seria Horticultură 2013;56(1):279-284.

13. da Silva PS, Barreto CF, Kirinus MBM, Schiavon AV, Malgarim MB, Mello-Farias P. Effects of Gibberellic acid (GA3) on reduction of rot disease and physicochemical quality of' Pinot Noir'grape. Australian Journal of Crop Science 2018;12(8): 1363.

14. Dimovska V, Ivanova V, Ilieva F, Sofijanova E. Influence of bioregulator gibberellic acid on some technological characteristics of cluster and berry from some seedless grape varieties. Journal of Agricultural Science and Technology 2011;1:1054-1058.

15. Eleonora N, Alina D, Dobrei A, Camen D, Matti GB. Cane girdling and gibberellic acid effects on yield and fruit quality of (Vitis vinifera L.) cv. Victoria and Italia. Journal of Horticulture, Forestry and Biotechnology, 2018;22(1):105-110.

16. FAO Crops. FAOSTAT. Food and Agriculture Organization of the United Nations 2014. Available at: http://www.fao.org/ Accessed on 10-08-2018.

17. FAO Crops. FAOSTAT. Food and Agriculture Organization of the United Nations 2017. Available at:http://www.fao.org/ Accessed on 11-01-2019.

18. Filimon RC, Filimon RV, Rotaru L. Changes In Yield And Quality Caracteristics Of Vitis Vinifera L. Cv. Muscat De Hamburg Under The Influence Of Gibberelic Acid (GA3).

19. Gadissa L. Effect of Gibberellic acid (GA3) and hedging on yield and yield related traits of Thompson Seedless grapevine (Vitis vinifera L.) in Central Rift Valley, Ethiopia. International Journal of Agriculture and Biosciences 2020;9(1):20-25.

20. Gao XT, Wu MH, Sun D, Li HQ, Chen WK, Yang HY, Effects of gibberellic acid (GA3) application before anthesis on rachis elongation and berry quality and aroma and flavour compounds in Vitis vinifera L. 'Cabernet Franc'and 'Cabernet Sauvignon'grapes. Journal of the Science of Food and Agriculture 2020.

21. Gokturk N, Harmankaya N. Changes in endogenous hormone levels during the ripening of grape cultivars having different berry set mechanisms. Turk J Agric Forest 2005;29:205-210.

22. Gowda VN, Shyamalamma S, Kannolli RB. Influence of GA3 on growth and development of Thompson Seedless grapes (Vitis vinifera L.). In X International Symposium on Plant Bioregulators in Fruit Production 2005;727:239242.

23. HE XR, Shan SM, Huang XC, Ping JC. Effects of Different Concentrations of Gibberellin Acid Treatment on Sugar Metabolism and Fruit Quality of 'Moldova' Grape Berries. Northern Horticulture 2013;21:7.

24. Hedden P, Kamiya Y. Gibberellin biosynthesis: enzymes, genes and their regulation. Ann Rev Plant Physiol \& Plant Mol Biol 1997;48:431-460.
25. Juan H, Chunbao G, Ping W, Qiangqing Z, Liang Z, Min W, Yujuan L. Effects of plant growth regulator on the fruit quality of Red Globe [J]. Sino-Overseas Grapevine \& Wine 2012,4.

26. Kaplan M. The effect of the method of application of growth regulators on fruit quality of" Einset seedless" grape (Vitis sp. L.). Acta Agrobotanica 2011;64(4).

27. Khan M, Hafeez-ur-Rahman A, Ahmed M, Abbas G, Ahmed N. Effect of gibberellic acid on growth and fruit yield of grape cultivar 'flame seedless'. International Journal of Biology and Biotechnology 2009;6(4):265268.

28. Kukali E, Thomaj T, Mane E. The Effect of Gibberellins on the Production Increase and Quality Improvements of Grape. Albanian Journal of Agricultural Sciences 2014;13(4).

29. Kumar TK, Sharma MK. Effect of GA3 in combination with urea phosphate and BA on yield and physical quality parameters of grape cv. Thompson Seedless. Progressive Horticulture 2017;49(2):133-137.

30. Lamjaroenphong W. Effects of berry thinning period and GA3 application to berry size and quality of Perlette grapes 2009.

31. Looney NE. Some growth regulator and cluster thinning effects on berry set and size, berry quality and annual productivity of the 'Chauna' grapes. Viticul 1981;20:2235 .

32. Magdalena K, Agnieszka N, Piotr B, Kamila K. Effect of gibberellic acid concentration and number of treatments on yield components of "Einset Seedless" grapevine cultivar. Hortic Sci 2017;44(4):195-200.

33. Magdalena K, Agnieszka N, Piotr B, Kamila K. Effect of gibberellic acid concentration and number of treatments on yield components of "Einset Seedless" grapevine cultivar. Horticultural Science 2017;44(4):195-200.

34. Mani M, Shivaraju CS, Srinivasa Rao. Pest of grapevine: a world wide list. Pest Management in horticultural ecosystems 2014;20(2):170-216.

35. Ruel JJ, Walker MA. Resistance to Pierce's disease in Muscadinia rotundifolia and other native grape species. Ame J Enol \& Viti 2006;57:158-165.

36. May P. From bud to berry, with especial reference to inflorescence and bunch morphology in Vitis vinifera $\mathrm{L}$. Aust J Grap Wine Res 2000;6:82-98.

37. Meena VS, Nambi VE, Vishawakarma RK, Gupta RK, Nangare DD. Effect of gibberellic acid on fruit quality and storability of grape in semi-arid region of Punjab. Agricultural Science Digest-A Research Journal 2012;32(4):344-347.

38. Mohamed AKA, El-Salhy AM, Mostafa RAA, El-Mahdy MT, Hussein AS. Effect of Exogenous Abscisic Acid (ABA), Gibberellic Acid (GA3) and Cluster Thinning on Yield of some Grape Cultivars. Journal of Plant Production 2019;10(2):101-105.

39. Mohsen FS. Improving Bunch and Berry Quality of Crimson Seedless Grape CV. Using Gibberellic Acid.

40. Nanjappanavar AG, Goudappanavar B, Patil DR. Quality and yield of grapes $\mathrm{cv}$. manik chaman influenced by application of gibberellic acid $0.001 \% 1$ in comparison to standard market sample. Indian Horticulture Journal, 2017;7(1):103-106.

41. Noori AM, Lateef MAA, Muhsin MH. Effect of phosphorus and gibberellic acid on growth and yield of grape (Vitis vinifera L.). Research on Crops 2018;19(4):643-648. 
42. Ollat N, Diakou-verdin P, Carde JP, Barrieu F, Gaudillere JP, Moing A. Grape berry development: A review. J Inter Sci Vig and Vine 2002;36:109-131.

43. Ozer C, Yasasin AS, Ergonul O, Aydin S. The effects of berry thinning and gibberellin on Recel Uzumu table grapes. Pak. J. Agri. Sci 2012;49(2):105-112.

44. Peacock B, Beede B. Improving maturity of,, Thampson Seedless $^{\text {ee }}$ for raisin production. Grape Notes, Tulaare, Californina 2004, 1-5.

45. Rusjan D. Impact of gibberellin (GA3) on sensorial qyality and srorability of table grape (Vitis vinifera L.) Acta Agric. Slovenica, 2010;95:163-173.

46. Samra B, Arafa SA. Effect of gibberellic acid and ethephon applications on berry color and quality of "flame seedless" grapes. Journal of Plant Production 2015;6(7):1131-1140.

47. Sangeetha J, Sivachandiran S, Selvaskanthan S. "Influence of Different Application Methods of Gibberellic acid (GA3) on Quality and Yield of Grapes (Vitis vinifera L.)." International Journal of Research, 2015, 10

48. Satidtawat I. Effects of berry thinning period and GA3 application to berry size and quality of Beauty Seedless grapes 2009.

49. Shamim-ul-Subtain Shah, Khan AK, Farooq MA, Riaz K, Chattha M, Gurmani M et al. Effects Of Gibberellic Acid On Growth, Yield And Quality Of Grape Cv. Perlet.

50. Tecchio MA, Botelho RV, Pires EJP, Terra MM, Hernandes JL. Effects of CPPU and gibberellic acid on morphological characters of cluster and berry of 'Vênus' grape. Acta Scientiarum-Agronomy 2006;28(4):507-511.

51. TIAN S. Changes of content and antioxidant activity of phenolic compounds during gibberellin-induced development of seedless Muscat grapevines. Acta horticulturae, 2014;1046:539-548.

52. Usha K, Kashyap D, Singh B. Corrigendum to: Influence of gibberellic acid and N6-benzyladenine on the development of seed and shot berries in the seedless grape (Vitis vinifera L.) cv. Perlette. Australian journal of agricultural research 2005;56(9):1009-1009.

53. Warusavitharana AJ, Tambe TB, Kshirsagar DB. Effect of cytokinins and brassinosteroid with gibberellic acid on yield and quality of Thompson Seedless grapes. Acta horticulturae 2008.

54. Wassel AH, El-Hameed MA, Gobara A, Attia M. Effect of some micronutrients, gibberellic acid and ascorbic acid on growth, yield and quality of white Banaty seedless grapevines. In 8th African Crop Science Society Conference, El-Minia, Egypt, 27-31 October African Crop Science Society 2007, 547-553. 